Article

\title{
Optimizing an Osteosarcoma-Fibroblast Coculture Model to Study Antitumoral Activity of Magnesium-Based Biomaterials
}

\author{
Philipp Globig ${ }^{1}\left(\mathbb{D}\right.$, Regine Willumeit-Römer $^{1}{ }^{(\mathbb{C}}$, Fernanda Martini $^{2}$, Elisa Mazzoni ${ }^{2}$ \\ and Bérengère J.C. Luthringer-Feyerabend ${ }^{1, * \mathbb{D}}$ \\ 1 Institute of Materials Research, Division for Metallic Biomaterials, Helmholtz-Zentrum Geesthacht (HZG), \\ 21502 Geesthacht, Germany; philipp.globig@hzg.de (P.G.); regine.willumeit@hzg.de (R.W.-R.) \\ 2 Department of Medical Sciences, University of Ferrara, 44121 Ferrara, Italy; fernanda.martini@unife.it (F.M.); \\ elisa.mazzoni@unife.it (E.M.) \\ * Correspondence: berengere.luthringer@hzg.de; Tel.: +49-4152-87-1292
}

Received: 17 June 2020; Accepted: 17 July 2020; Published: 19 July 2020

check for updates

\begin{abstract}
Osteosarcoma is among the most common cancers in young patients and is responsible for one-tenth of all cancer-related deaths in children. Surgery often leads to bone defects in excised tissue, while residual cancer cells may remain. Degradable magnesium alloys get increasing attention as orthopedic implants, and some studies have reported potential antitumor activity. However, most of the studies do not take the complex interaction between malignant cells and their surrounding stroma into account. Here, we applied a coculture model consisting of green fluorescent osteosarcoma cells and red fluorescent fibroblasts on extruded $\mathrm{Mg}$ and $\mathrm{Mg}-6 \mathrm{Ag}$ with a tailored degradation rate. In contrast to non-degrading Ti-based material, both $\mathrm{Mg}$-based materials reduced relative tumor cell numbers. Comparing the influence of the material on a sparse and dense coculture, relative cell numbers were found to be statistically different, thus relevant, while magnesium alloy degradations were observed as cell density-independent. We concluded that the sparse coculture model is a suitable mechanistic system to further study the antitumor effects of Mg-based material.
\end{abstract}

Keywords: cancer; osteosarcoma; magnesium; coculture; degradation

\section{Introduction}

Osteosarcoma (OS) is the most common malignancy of primary bone arising from mesenchymal (bone-forming) cells. This tumor is predominantly found in children and adolescents, with $75 \%$ of patients ranging from 15 to 25 years [1]. OS resides in the eighth position among the most common cancers in children (around 2.4\%) and accounts for around $8.6 \%$ (bones and joints) of cancer-related deaths in children [2-4]. The prevalence of osteosarcoma in young patients is increasing to 6-8 million/year [5-8]. The World Health Organization classifies OS into central (or medullary; $90 \%$ of reported cases) and surface (peripheral) tumors, both with various subtypes [1]. Low-grade osteosarcomas can be treated by surgical resection, which can lead to complications during treatment, including bone defects from excised tumor tissue [1,9]. High-grade diagnosed tumors require neoadjuvant and adjuvant chemotherapies, e.g., applying methotrexate, doxorubicin, and cisplatin [9-11]. Long-lasting systemic treatments, such as chemotherapy, often come along with severe side effects like nausea and vomiting that dramatically deteriorate the everyday life of the patients. Promising alternatives to overcome these side effects are drug delivery systems, for instance, liposomes and polymer micelles for drug encapsulation, which directly target the tumor side [12].

Another novel approach combining temporary bone replacement for small bone defects after tumor resection and local treatment could be the use of magnesium (Mg)-based biomaterials. Owing to 
their good biocompatibility and full degradability in physiological environments [13], Mg materials have already been widely discussed for orthopedic applications. Mg degradation is accompanied by a constant ion and hydrogen gas $\left(\mathrm{H}_{2}\right)$ release, as well as increasing $\mathrm{pH}$ and osmolality at the material surface microenvironment. These surface-near effects may also specifically affect residual tumor cells that are inaccessible for surgery if the degradation is tailored for exactly this application. Some recent studies have already reported a certain cytotoxic effect of $\mathrm{Mg}$ degradation on tumor cells [14-16]. Furthermore, alloying of $\mathrm{Mg}$ with elements like silver $(\mathrm{Ag})$ holds the potential to additionally influence the degradation rate, mechanical properties, and biological response. $\mathrm{Mg}-\mathrm{Ag}$ alloys have been already shown to have antibacterial effects [17], and they may also prevent carcinogenic progression as Ag also possesses anticancer properties $[18,19]$. Ensuring tumor cell-specific cytotoxicity and the simultaneous integrity of adjacent healthy cells is one major challenge when investigating Mg-based materials for the use in cancer therapy. Therefore, tailoring the degradation rate for this purpose is important. While Mg materials in orthopedic applications require very low degradation rates to avoid damages in the adjacent tissues and increase the implant lifetime, tumor therapy approaches demand other strategies. The degradation rate and resulting surface-near effects (increased $\mathrm{pH}$, osmolality, and $\mathrm{H}_{2}$ release) should be tailored high enough to kill tumor cells but as low as possible to ensure the integrity of the surrounding healthy tissue. Additionally, such a tumor therapy may benefit from a higher tumor cell sensitivity towards Mg degradation compared to healthy cells, as described by others [20].

Furthermore, it is important to consider the complexity of the tumor microenvironment (TME). Tumors do not only consist of malignant tumor cells but also recruit different cell types into their proximity, where non-tumorous cells often have a positive effect on tumor growth and progression [21,22]. These cells include fibroblasts and cells of the vasculature and immune system summarized in the stroma. Fibroblasts play a very specific role in the TME since they are responsible for the communication of tumor and stromal cells by secreting cytokines [23] and seem to regulate progression and metastases of tumors [24,25]. Multiple studies show that $\mathrm{Mg}$ may intervene in this communication between tumor cells and stroma [26-29]. To enable an in-depth study of the $\mathrm{Mg}$ influence on the interaction of tumor and stroma, a meaningful cell model is required. Coculture models should be preferred over simple monoculture systems since they allow the interaction of cell types (transmission of cytokines) and depict in-vivo situations better. Furthermore, a direct coculture allows the proximity and physical interaction of the different cell types. Coculture models, including tissue-specific tumor cells and fibroblasts, are generally accepted as tumor models not only for OS [30] but also for other tumor types, such as mammary cancer [31,32] or pancreatic tumor [33,34].

Based on these publications, we established a 1:1 coculture system consisting of green fluorescent osteosarcoma cells (Saos-eGFP) and red fluorescent dermal fibroblasts (RF fibroblasts) in direct contact with the Mg material. This chosen ratio was in accordance with in vivo reported carcinoma-percentage derived from the carcinoma-stromal ratio, i.e., $20 \%$ to $90 \%$ (here 50\%) [35]. In contrast to the aforementioned studies that used a coculture test system on inert tissue culture plastic, we were challenged with the degradation of Mg-based materials, that is, on the one hand, influenced by the cells and, on the other hand, can impact the cells [36-41]. The aim of this study was to investigate the influence of Mg-based materials on tumor and healthy cells in future studies. To identify influences of our material on our coculture and find the optimal seeding conditions, two cell densities, namely, a sparse (10,000 cells in total) and a dense (50,000 cells in total) coculture, were compared regarding their suitability for an appropriate coculture model. Thus, we investigated whether $\mathrm{Mg}$ and $\mathrm{Mg}-6 \mathrm{Ag}$ have a significant influence on the ratio of both seeded cell types. Furthermore, we explored possible cell-dependent influences on the material degradation, namely, the mean degradation rate (MDR), $\mathrm{pH}$, osmolality, and ion release, to exclude that $\mathrm{Mg}$ degradation effects cause differences between the sparse and dense model. 


\section{Results}

\subsection{Effect of Extruded $\mathrm{Mg}$ and $\mathrm{Mg}-6 \mathrm{Ag}$ on Tumor Cell to Healthy Cell Number Ratio}

First, both cell proliferation rates were confirmed to be similar over a culture period of seven days (Figure 1A), ascertaining that further obtained observations were not biased. It was further confirmed that fibroblasts did not acquire a cancer-associated fibroblastic phenotype in coculture with Saos-eGFP via $\alpha$-smooth muscle actin ( $\alpha$-SMA) staining (Appendix A Figure A1). Then, the difference of relative cell numbers between the sparse (10,000 cells in total) and dense (50,000 cells in total) coculture model (tumor cell:healthy cell ratio 1:1) on $\mathrm{Mg}$ and $\mathrm{Mg}-6 \mathrm{Ag}$ degradation was tested. The materials were chosen to compare the effects of degradation products (Mg samples, degradation products: H-release, $\mathrm{pH}$ change, increase of $\mathrm{Mg}$ ions in the vicinity of the material) with the toxicity, which should come from the functionalization of the material by $\mathrm{Ag}$ (Mg-6Ag samples). The degradation rate was similar for both materials (see Figure 2 for details) and in a range that is usually well tolerated by cells. Microscopic images of the whole surface of the disk (Figure 1B) were taken one, three, and seven days after seeding. Cells were counted, and the resulting ratios were determined (Figure 1C-E). Comparing the different materials, it seemed that the degrading $\mathrm{Mg}$ and $\mathrm{Mg}-6 \mathrm{Ag}$ favored the growth of healthy fibroblasts compared to the control (Ti-6Al-4V). Within the period of seven days, the cell ratio of tumor cells (Saos-eGFP) declined on $\mathrm{Mg}$ from 65 to $50 \%$ in the dense model and from 62 to $37 \%$ in the sparse model. The healthy cell ratio (red fluorescent or RF fibroblasts) increased on $\mathrm{Mg}$ from 35 to $50 \%$ in the dense model and 38 to $63 \%$ in the sparse model. Seeding on $\mathrm{Mg}-6 \mathrm{Ag}$ showed similar results (tumor cells: 68 to $50 \%, 62$ to $42 \%$; healthy cells: 32 to $50 \%$, 38 to $58 \%$ ). Opposite results were obtained with non-degrading Ti-6Al-4V (control). Here, the ratio of tumor cells increased from 65 to $81 \%$ (dense) and 71 to $83 \%$ (sparse model), while the relative cell number of healthy cells decreased from 35 to 19\% (dense) and 30 to 18\% (sparse model) within seven days. Interestingly, the proportion of fibroblasts was significantly higher in the sparse model compared to the dense coculture model on day 3. Furthermore, on extruded $\mathrm{Mg}$ and $\mathrm{Mg}-6 \mathrm{Ag}$, the proportion of fibroblasts tended to be higher in the sparse model compared to the dense coculture model. Absolute cell numbers of Saos-eGFP and RF fibroblasts did not show significant changes between coculture and monocultures. Though for the coculture in control, absolute tumor cell numbers (sparse model) strongly increased compared to the tumor cells in monoculture within seven days. Regarding $\mathrm{Mg}$ and $\mathrm{Mg}-6 \mathrm{Ag}$, tumor cell numbers were decreasing in the monocultures while remaining constant or slightly increased in the coculture. 


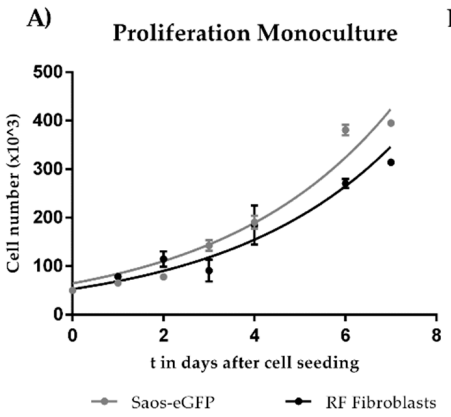

C)

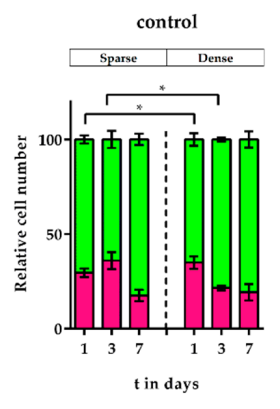

D)

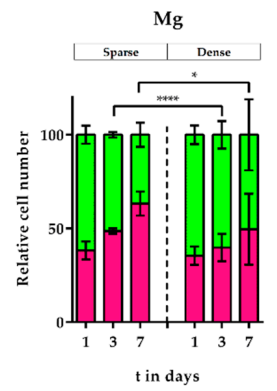

E)

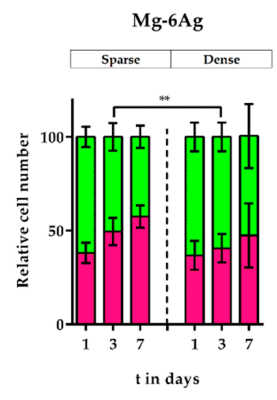

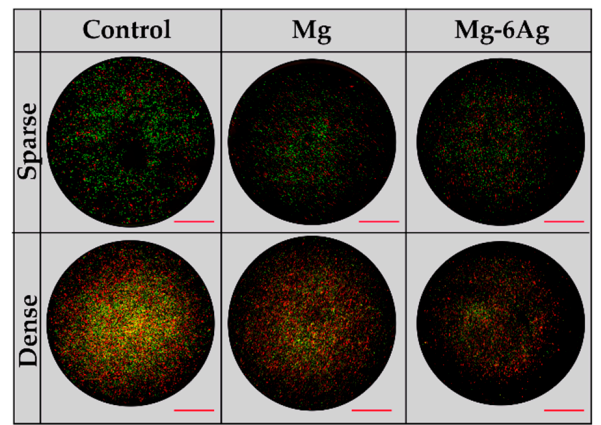

Coculture on control

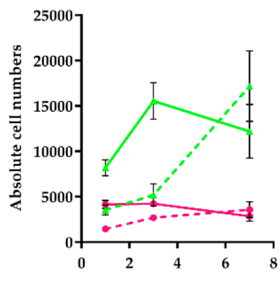

tin days
$\square /-$ RF Fibroblasts $\quad \square / \neq$ Saos-GGFP

Coculture on Mg

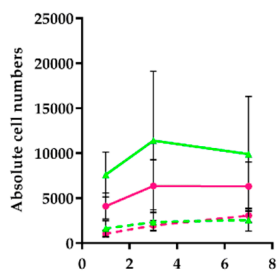

$t$ in days

$\square / \rightarrow$ RF Fibroblasts $\quad \square / \nrightarrow$ Saos-eGFP

Coculture on Mg-6Ag

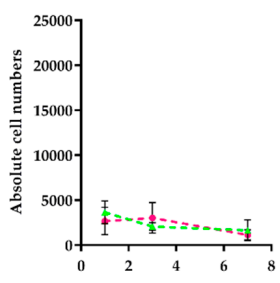

$t$ in days

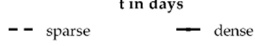

Monoculture on Mg-6Ag

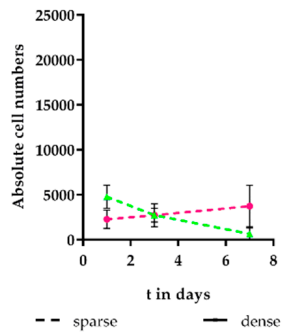

Figure 1. Influence of Mg-based materials on relative healthy and tumor cell numbers. (A) Cell proliferation of monocultures on tissue culture plastic. Significance differences between proliferation rates of Saos-eGFP (green fluorescent osteosarcoma cells) and RF fibroblasts (red fluorescent dermal fibroblasts) were obtained via extra sum-of-squares $\mathrm{F}$ test of non-linear regression curves. (B) Exemplary and representative pictures of the sparse and dense coculture on control (Ti-6Al-4V), $\mathrm{Mg}$, and Mg-6Ag at day 1. Scale bar is $2.5 \mathrm{~mm}$. (C-E) Evolution of cell populations (i.e., relative cell numbers, absolute cell numbers) of the tumor (Saos-eGFP; green) and healthy cells (RF fibroblasts; purple) in coculture and monoculture over seven days. Relative and absolute cell numbers were presented as the arithmetical mean \pm SD of three independent experiments. Significance differences between samples of the respective time points from the dense and sparse model were obtained via a Mann-Whitney test $(n=9)$; $*=p<0.05 ;^{* *}=p<0.01 ;{ }^{* * * *}=p<0.0001$. 
A)

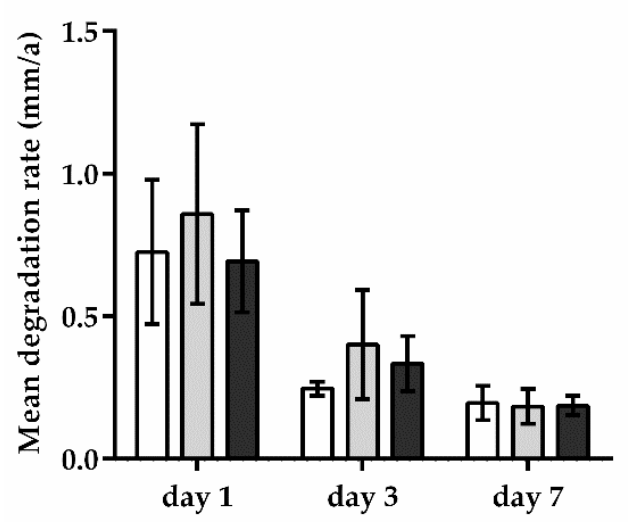

No-cell
Mg

day 7
B)

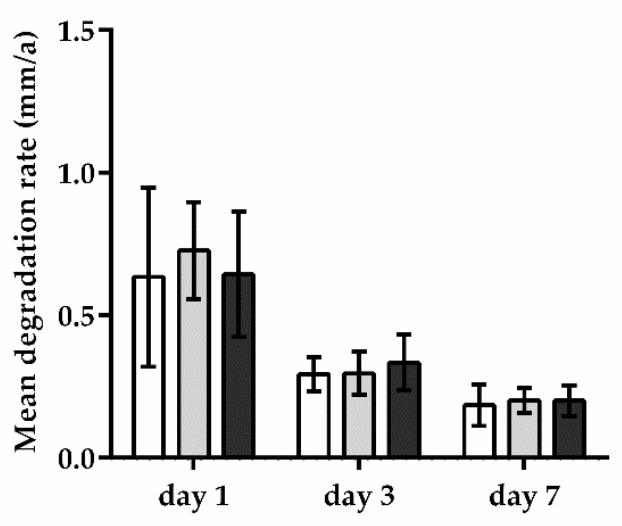

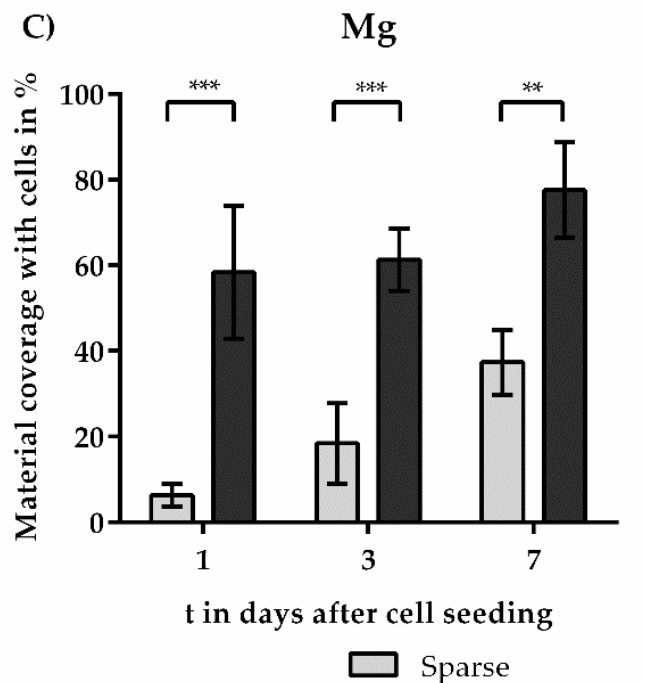

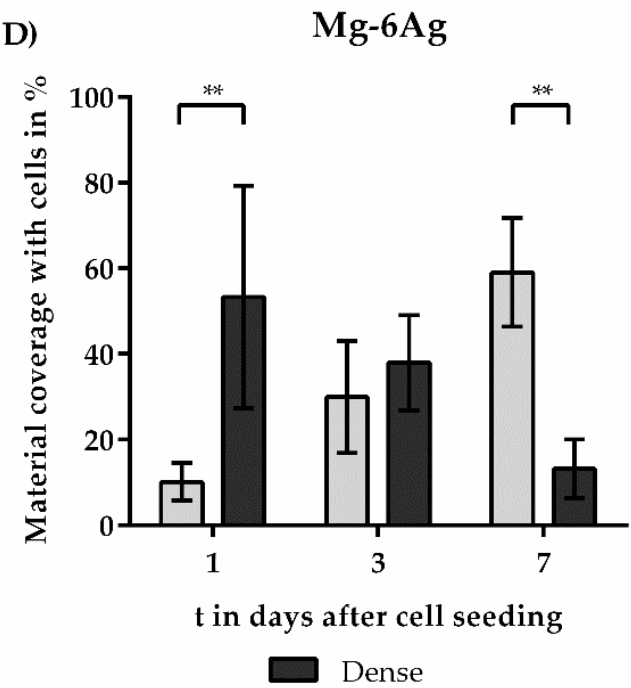

Figure 2. Comparison of mean degradation rates (MDRs) and cell densities on extruded $\mathrm{Mg}$ and Mg-6Ag. (A,B) MDR and (C,D) respective proportions of material coverage were presented as the arithmetical mean \pm SD of three independent experiments. Significance differences between samples of the respective time points from no-cell control, the dense, and sparse model were obtained via a Kruskal-Wallis $\mathrm{H}$ test with Dunn's multiple comparison test $(\mathbf{A}, \mathbf{B})$ or via a Mann-Whitney test $(\mathbf{C}, \mathbf{D})$ $(n=9){ }^{* *}=p<0.01,{ }^{* * *}=p<0.001$.

\subsection{Comparison of Material Degradation Rates, $p H$, and Osmolalities}

The viability of cells on cytocompatible Mg-based materials was majorly influenced by material degradation, namely, the mean degradation rate (MDR) accompanied by, e.g., a certain increase in $\mathrm{pH}$ and osmolality. The MDR was determined via mass loss at days 1,3, and 7 after cell seeding. Figure 2 shows the comparison of MDR and material coverage for $\mathrm{Mg}$ and $\mathrm{Mg}-6 \mathrm{Ag}$. MDR of both $\mathrm{Mg}$ and $\mathrm{Mg}-6 \mathrm{Ag}$ did not differ significantly between the dense and sparse coculture models. Furthermore, there was no significant difference for MDR between cell-seeded and no-cell samples (Figure 2A,B). However, the proportion of material surface that was covered by cells differed significantly between the sparse and dense coculture model (except for $\mathrm{Mg}-6 \mathrm{Ag}$ on day 3) (Figure 2C,D). On Mg, cell density elevated from 58 to $78 \%$ in the dense model and from 6 to $37 \%$ in the sparse coculture model within 
seven days. On Mg-6Ag, the sparse model coverage rose from 10 to $61 \%$, whereas in the dense model, it diminished from 59 to $13 \%$.

Furthermore, the $\mathrm{pH}$ and osmolalities were measured one, three, and seven days after cell seeding. Figure 3 shows the $\mathrm{pH}$ and osmolality for cell-seeded samples (sparse/dense) and no-cell controls for up to seven days. There was no significant change in $\mathrm{pH}$ and osmolality for both coculture models.
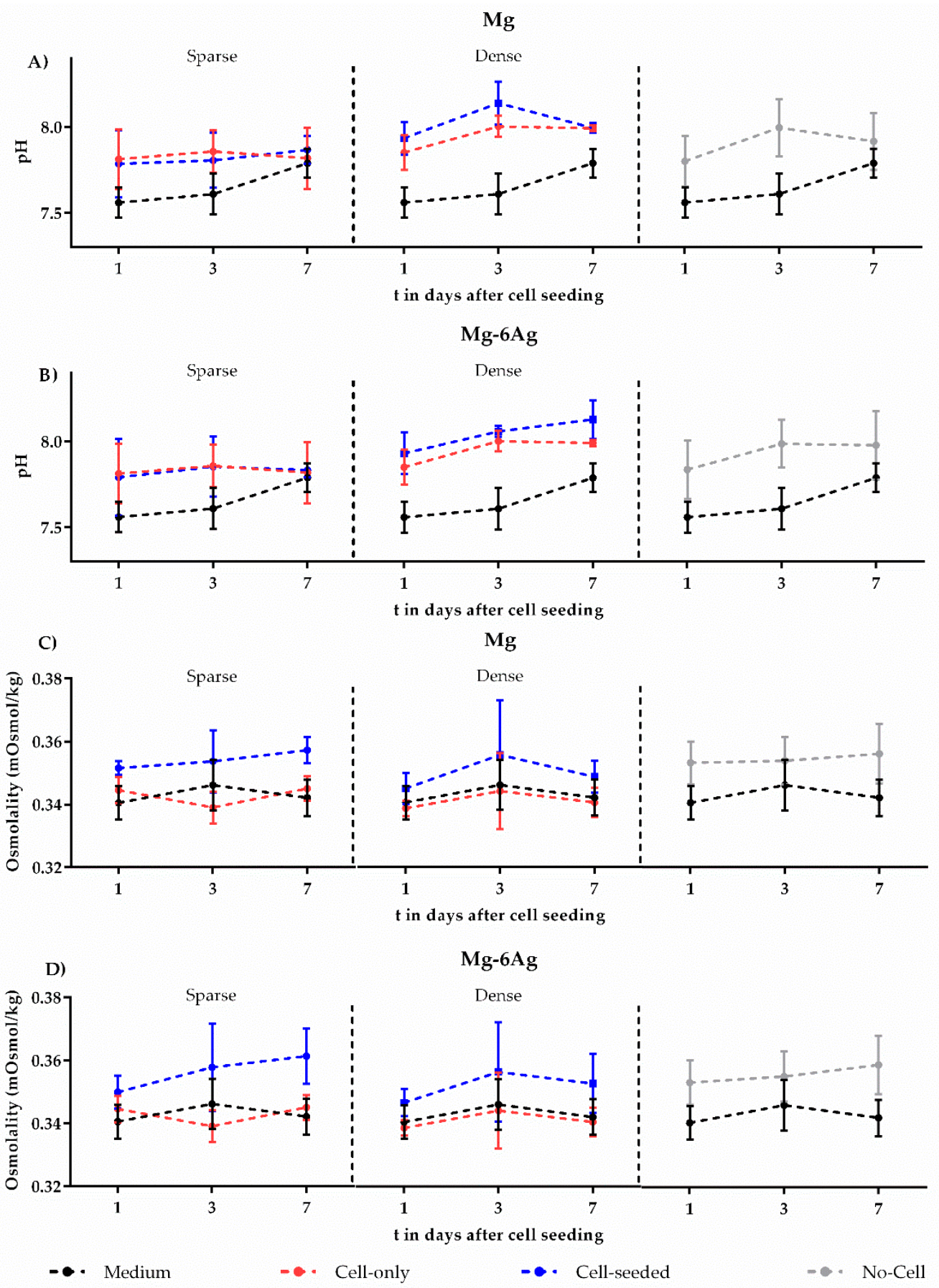

Figure 3. Measurement of $\mathrm{pH}$ and osmolality. (A, $\mathbf{B}) \mathrm{pH}$ and $(\mathbf{C}, \mathbf{D})$ osmolality of cell-seeded (sparse/dense) and no-cell control for up to seven days. Osmolality and $\mathrm{pH}$ values were presented as the arithmetical mean \pm SD of three independent experiments. Significance differences between samples of the respective time points from no-cell control, the dense, and sparse model were obtained via a Kruskal-Wallis H test with Dunn's multiple comparison test $(n=9)$. 


\subsection{Surface Topology of Initial and Degraded $\mathrm{Mg}$ and $\mathrm{Mg}-6 \mathrm{Ag}$}

To investigate possible influences of the material surface on the proliferation of the cells, images of the surface topology were taken using a white light interferometer (Figure 4). Color scale bars indicated the range between the highest point (peak) and the lowest point (valley) on the material surface. Images of $\mathrm{Mg}$ and $\mathrm{Mg}-6 \mathrm{Ag}$ in an initial state after grinding are shown in Figure 4A,B. The investigated parameters, namely, average roughness $(\mathrm{Sa})$, the maximum peak height $(\mathrm{Sp})$, the maximum valley depth (Sv), and the peak-valley difference (PVD), were comparable for $\mathrm{Mg}$ and $\mathrm{Mg}-6 \mathrm{Ag}$. Furthermore, the surface morphologies of the sparse (right half) and dense (left half) coculture after seven days degradation and after removal of the degradation layer are shown for $\mathrm{Mg}$ (Figure $4 \mathrm{C}$ ) and $\mathrm{Mg}-6 \mathrm{Ag}$ (Figure 4D). On both $\mathrm{Mg}$ and $\mathrm{Mg}-6 \mathrm{Ag}$, the average roughness did not differ but was increased compared to the samples in the initial state. On Mg, the PVD of the sample with the sparse model was increased compared to the sample with the dense coculture. In contrast to that, the PVD of both $\mathrm{Mg}-6 \mathrm{Ag}$ samples was comparable.
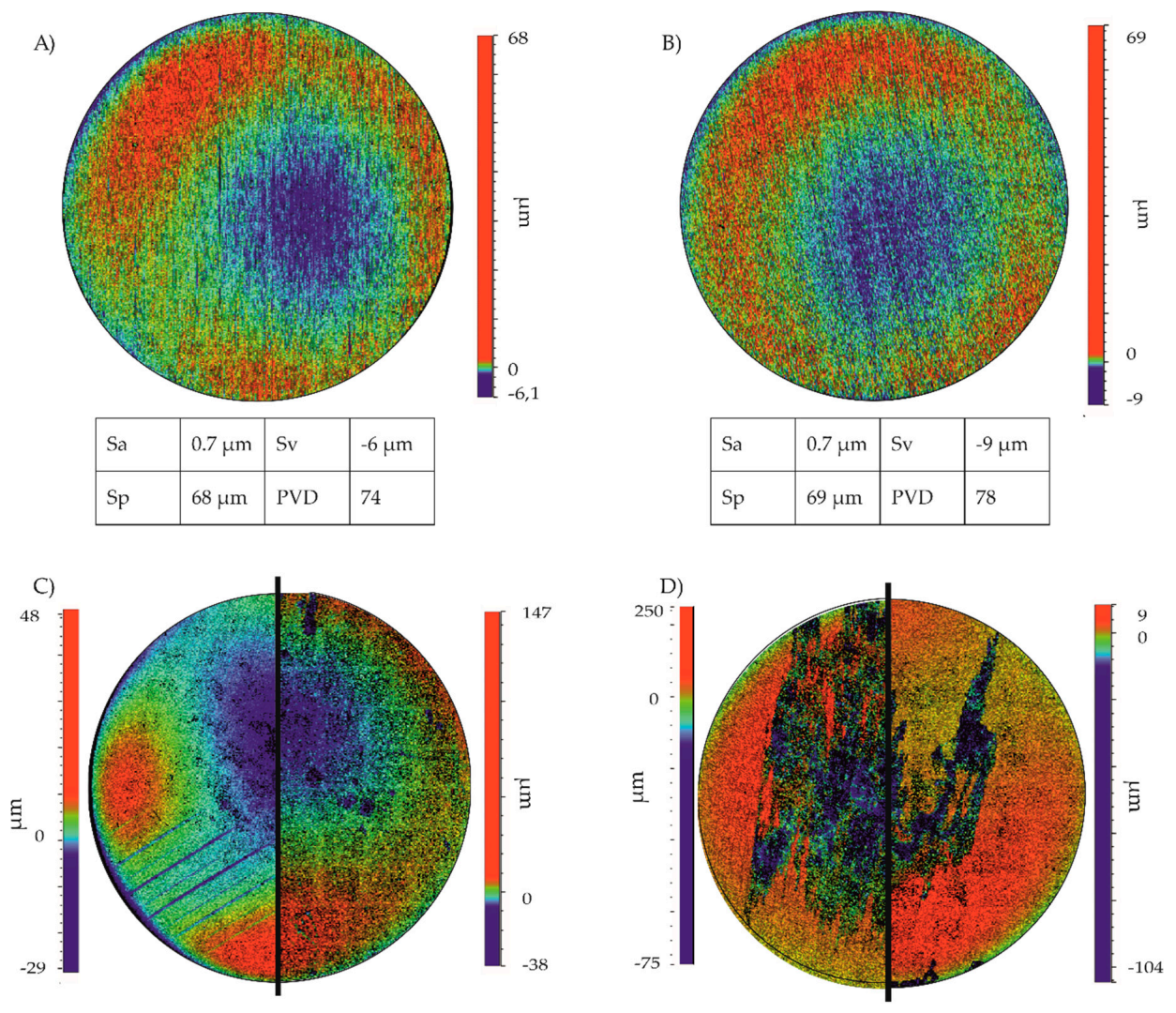

\begin{tabular}{|l|l||l|l|l|}
\hline Sa & $3 \mu \mathrm{m}$ & Sa & $3 \mu \mathrm{m}$ \\
\cline { 1 - 2 } Sp & $46 \mu \mathrm{m}$ & Sp & $143 \mu \mathrm{m}$ \\
\hline Sv & $-29 \mu \mathrm{m}$ & SV & $-36 \mu \mathrm{m}$ \\
\hline PVD & 75 & PVD & 179 \\
\hline
\end{tabular}

\begin{tabular}{|l|l|}
\hline Sa & $3 \mu \mathrm{m}$ \\
\hline Sp & $9 \mu \mathrm{m}$ \\
\hline Sv & $-106 \mu \mathrm{m}$ \\
\hline PVD & 115 \\
\hline
\end{tabular}

\begin{tabular}{|l|l|}
\hline Sa & $4 \mu \mathrm{m}$ \\
\hline Sp & $25 \mu \mathrm{m}$ \\
\hline Sv & $-76 \mu \mathrm{m}$ \\
\hline PVD & 101 \\
\hline
\end{tabular}

Figure 4. The surface topology of $\mathrm{Mg}$ and $\mathrm{Mg}-6 \mathrm{Ag}$. (A) $\mathrm{Mg}$ and (B) $\mathrm{Mg}-6 \mathrm{Ag}$ as samples in an initial state after grinding are shown. (C) The surface topology of $\mathrm{Mg}$ and (D) Mg-6Ag seeded with the sparse (right half) and dense coculture (left half) after degradation and removal of the degradation layer. To compare the surface morphologies of respective samples with the sparse and dense coculture, the average roughness $(\mathrm{Sa})$, the maximum peak height $(\mathrm{Sp})$, the maximum valley depth $(\mathrm{Sv})$, and the peak-valley difference (PVD) are shown. 


\subsection{Quantification of Alloying Elements in the Supernatant}

To investigate possible anti-cancerous effects of alloying elements, ion releases were quantified by atomic absorption spectroscopy (AAS) or inductively-coupled plasma-mass spectrometry (ICP-MS) in the supernatant after 1,3, and 7 days culture for the sparse and dense coculture models (Figure 5).

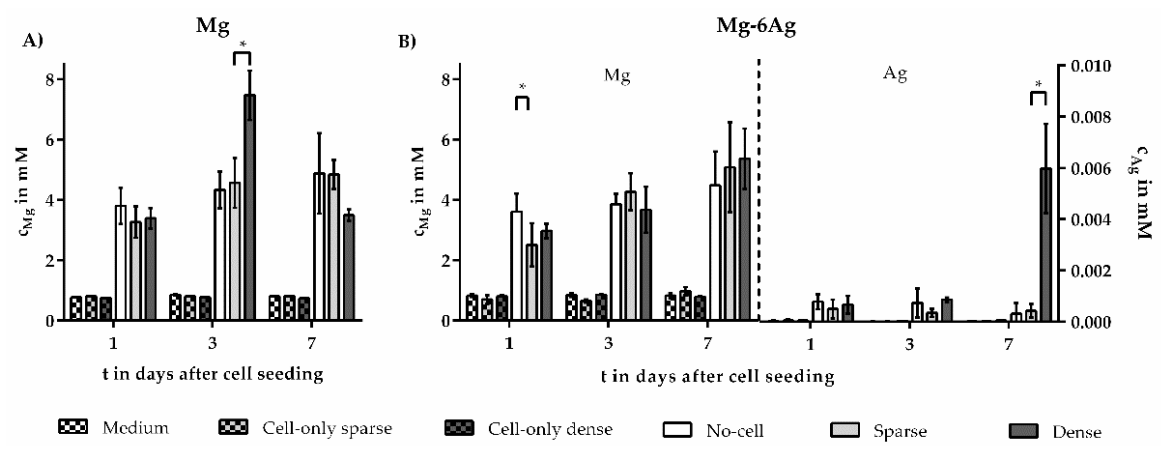

Figure 5. Quantification of $\mathrm{Mg}$ and $\mathrm{Ag}$ contents in degradation supernatants. (A) Mg content quantified using atomic absorption spectroscopy (AAS). (B) Co-existing $\mathrm{Mg}$ and $\mathrm{Ag}$ content in the supernatant of degrading Mg-6Ag quantified by inductively-coupled plasma-mass spectrometry (ICP-MS). $\mathrm{Mg}$ and Ag contents of cell-seeded samples were corrected by subtracting cell-only control; no-cell control corrected by subtracting medium. $\mathrm{Mg}$ and $\mathrm{Ag}$ contents were presented as the arithmetical mean $\pm \mathrm{SD}$ of three independent experiments. Significance differences between samples of the respective time points from no-cell control, the dense, and sparse model were obtained via a Kruskal-Wallis H test with Dunn's multiple comparison test $(n=6$ or 9$){ }^{*}=p<0.05$.

$\mathrm{Mg}$ concentration increased over time, increasing from 2.5-5.0 $\mathrm{mM}$ in the sparse model and from 2.2-4.6 $\mathrm{mM}$ in the dense model. Comparing the ion release after $\mathrm{Mg}-6 \mathrm{Ag}$ degradation, $\mathrm{Mg}$ and $\mathrm{Ag}$ ion concentrations in the sparse and dense coculture model did not differ significantly. This was also true when comparing respective cell-seeded and cell-free samples, except for control and sparse model at day one. In the sparse model, Ag ion concentration scattered around $0.4 \mathrm{nM}$, while in the dense coculture model, it rose from 0.6 to $0.8 \mathrm{nM}$ during the first three days and elevated to $6 \mathrm{nM}$ until day seven. $\mathrm{Mg}$ ion release after $\mathrm{Mg}$ degradation showed majorly no significant difference between the sparse and dense coculture model, except at day three.

\section{Discussion}

In our study, we used a 1:1 coculture (starting condition) of green fluorescent human osteosarcoma cells (Saos-eGFP) and red fluorescent human dermal fibroblasts to establish a simplified in vitro osteosarcoma model. This mechanistic model should enhance the relevance of prospective studies that will test the influence of Mg-based biomaterials and degradation-induced surface effects on tumor and healthy cells of the TME. The coculture model established in our study created a more complex environment, which was closer to the actual in vivo situation compared to using a monoculture of tumor cells only. Recent studies have shown that tumor cell-fibroblasts cocultures can be beneficial to improve tumor models [30-34]; nevertheless, the application of such a coculture to test Mg-based biomaterials for antitumor activity is to our knowledge entirely new. Specifically, for a model studying the interaction of bone-derived cells with $\mathrm{Mg}$, Burmester et al. suggested Saos-2 cells to be more appropriate than, e.g., MG63 or U2OS [42,43], based on their study in a monoculture system. Furthermore, Saos-2 is the only cell line of the above-mentioned that is able to mineralize $[44,45]$. Based on this, we chose Saos-eGFP, which originated from Saos-2 osteosarcoma cells, for our osteosarcoma-fibroblast coculture.

Furthermore, fluorescently labeled cells allowed not only the visualization and distinction of both cell types in the coculture directly on the opaque material but also made this coculture a potent monitoring system. As shown in the microscopic images of Figure 1, the cells were generally viable on all materials. Nevertheless, there were substantial differences between the relative cell numbers on 
degrading (Mg, Mg-6Ag) and non-degrading (Ti-6Al-4V) material, as shown in Figure 1C-E. On Mg and $\mathrm{Mg}-6 \mathrm{Ag}$, relative healthy fibroblast numbers showed a cell density-independent tendency towards an increase within the observation time (days 1-7). In contrast to this, relative tumor cell numbers increased on the non-degrading Ti-based material. These effects were material-specific as both cells exhibited rather similar proliferation rates. Compared to the findings in the coculture, tumor cell numbers in the monoculture were decreasing on $\mathrm{Mg}$ and $\mathrm{Mg}-6 \mathrm{Ag}$. This indicated relevant crosstalk between tumor cells and surrounding cells in vivo (in this case, fibroblasts) that could not occur in monoculture. Therefore, investigating materials for their anticancer activity should not only be done in monocultures since the results may not be relevant.

Degradable materials, such as $\mathrm{Mg}$ and $\mathrm{Mg}-6 \mathrm{Ag}$, favored the growth of healthy cells over the malignant cell proliferation, indicating the general suitability of these materials for anticancer approaches. Degradability and accompanying surface effects might be one reason for the differences in relative cell numbers on Mg-based materials and non-degrading controls. Future studies should clarify whether this was due to increased tumor cell cytotoxicity or inhibited proliferation. Furthermore, recent publications have also shown favorable effects for healthy cells of the tumor microenvironment $[46,47]$ and unfavorable effects on osteosarcoma cells [43]. However, these findings have been obtained only in monocultures and majorly using Mg extracts and salt solutions, so these results should be interpreted with caution regarding our results.

Moreover, we compared two different cell densities of the established coculture, namely, a sparse $(10,000$ cells in total) and a dense (50,000 cells in total) system. For the sparse model, relative tumor cell numbers were significantly lower at day $3(\mathrm{Mg}, \mathrm{Mg}-6 \mathrm{Ag})$ and day $7(\mathrm{Mg})$ compared to the dense model. Possible explanations included: (I) A different degradation rate, $\mathrm{pH}$, and osmolality of the $\mathrm{Mg}$ substrates, (II) A different $\mathrm{Mg}$ and Ag release or a different impact of these elements on the cells, (III) A different cell proliferation behavior due to contact inhibition.

It is known that cells can alter Mg degradation, which, in turn, can affect the number of cells surviving on the material surface. However, detailed cell-material interaction remains ambiguous, and cells influence $\mathrm{Mg}$ material degradation that appears to be highly cell-type and substrate-dependent. Based on the, respectively, studied monoculture systems, the literature indicates that the degradation may be inhibited [36,37], stimulated [38-40], or not affected by cells [48]. Our approach of using such a coculture was new, and, therefore, comparisons must be interpreted with caution. Figure 2A,B shows that the degradation rate of the material was not significantly affected by the different cell numbers in the two coculture models. Moreover, Figure 2C,D proves that the initial different cell numbers in the sparse and dense model remained significantly different after seeding. This confirmed the cell-density independence of the degradation of the studied coculture system. The degradation of Mg-based materials also increases the $\mathrm{pH}$ and osmolality of the surrounding [17,41,49-51]. Figure 3 shows that neither the $\mathrm{pH}$ nor the osmolality was significantly different between the sparse and dense coculture model. Based on the comparison of degrading and non-degrading material, the degradation might have an influence on the relative cell numbers of the coculture. But as shown by the MDR, $\mathrm{pH}$, and osmolality, the differences between sparse and dense coculture seemed not to be majorly influenced/caused by cell-density-dependent altered degradation rates.

Another possibility for the different relative cell numbers between sparse and dense coculture models might be a different amount of released ions during the degradation of Mg-based materials. $\mathrm{Mg}$ and Ag may act extracellularly or intracellularly with the cells. Therefore, the concentrations of $\mathrm{Mg}$ and $\mathrm{Ag}$ in the supernatant of degrading $\mathrm{Mg}$ and $\mathrm{Mg}-6 \mathrm{Ag}$ were measured by AAS and ICP-MS. We quantified $\mathrm{Mg}$ concentrations between 1-6 mM in the supernatant, which was in the expected range supported by other studies [52-57]. In general, no significant correlation between ion release and cell ratios could be stated. For $\mathrm{Mg}-6 \mathrm{Ag}$, the release of $\mathrm{Mg}$ and $\mathrm{Ag}$ tended to be higher in the control and dense model compared to the sparse model. Since the MDR of the control, dense, and sparse model did not significantly differ, a degradation influence could be excluded. Though, we could measure a significant difference in a few samples. Lower concentrations might be explained by ions 
bound to degradation products on the material surface. Since the quantification of $\mathrm{Mg}$ and $\mathrm{Ag}$ was performed using the supernatant of the immersion test, accumulated silver on the material or insoluble degradation products, such as $\mathrm{Mg}(\mathrm{OH})_{2}$ or $\mathrm{MgCO}_{3}$, could not be taken into account for AAS and ICP-MS $[17,49]$. Alternatively, the different concentrations between sparse and dense models might be explained by an increased uptake of $\mathrm{Mg}$ and $\mathrm{Ag}$ by cells. In contrast to healthy cells, tumor cells have a certain avidity for extracellular $\mathrm{Mg}$, which results in increased $\mathrm{Mg}$ accumulations in the tumor cells [58]. Mg is involved in the regulation of various enzymes involved in glycolysis or metabolism of nucleic acids and proteins [59-61], underlining its proliferation-stimulating effect in tumor cells. This was in contradiction to our findings, in which relative tumor cell numbers decreased on Mg-based material. A possible explanation might be the antagonism of $\mathrm{Mg}$ to calcium (Ca). Sun and colleagues reported an increased extracellular serum $\mathrm{Ca} / \mathrm{Mg}$ ratio in prostate cancer patients. They could see that the increased $\mathrm{Ca} / \mathrm{Mg}$ ratio in vitro resulted in a massive $\mathrm{Ca}$ influx, followed by increased tumor cell proliferation [62]. Consequently, shifting the ratio towards the magnesium would inhibit $\mathrm{Ca}$ influx and tumor cell proliferation. These findings were also supported by the work from Pereira et al. The authors observed an inhibited chemically triggered Ca influx through the plasma membrane of MCF-7 cells in the presence of high extracellular Mg levels [63]. Normally, Ca influxes the cells following absorption to mitochondria and the endoplasmic reticulum. Ca-dependent processes like cell proliferation result in depletion of $\mathrm{Ca}$ in the endoplasmic reticulum, which again triggers Ca influx, a process called store-operated calcium entry $[64,65]$. Increased external $\mathrm{Mg}$ levels have been reported to inhibit this process $[66,67]$. Consequently, this would reduce cell proliferation in theory, supporting our findings for the relative cell numbers on $\mathrm{Mg}$ and $\mathrm{Mg}-6 \mathrm{Ag}$ from Figure 1D,E.

Furthermore, cells of the tumor stroma, such as fibroblasts, are affected by $\mathrm{Mg}$. Yue et al. showed that Mg supplementation decreased the production of matrix metalloproteinases (MMP) in fibroblasts [28]. These MMPs are important for remodeling the extracellular matrix and subsequent migration and invasion of adjacent tumor cells. $\mathrm{Ag}$ is influencing tumor cells mainly via the interaction with proteins and the DNA [68]. This leads to proliferation inhibition [69], induces oxidative stress [70], or even apoptosis [68,71]. Nonetheless, the question arises whether the released Ag concentration in our study is sufficient to induce tumor cell death while preserving healthy cell viability. Literature indicates a large concentration span of $\mathrm{IC}_{50}$ (half maximal inhibitory concentration) of Ag sources for different tumor types. The $\mathrm{IC}_{50}$ of $\mathrm{AgNO}_{3}$ has been reported at $6.75 \mu \mathrm{M}$ for H-ras transformed 5RP7 (rat embryonic fibroblasts) [72] and between 0.19 and $0.37 \mathrm{mM}$ for Hela cells [73]. For Ag-ions and colloidal $\mathrm{Ag}$, other authors have reported an $\mathrm{IC}_{50}$ of $0.31 \mathrm{mM}$ and $32.45 \mu \mathrm{M}$, respectively, for breast cancer cells $[19,74]$. Our results showed that the concentration of released $\mathrm{Ag}(0.7 \mathrm{nM})$ was not comparable to the $\mathrm{IC}_{50}$ values reported in the other publications. From our data, it was unclear up to what extent the released $\mathrm{Mg}$ and $\mathrm{Ag}$ affected both cell types. This requires the visualization and quantification of intracellular free or bond $\mathrm{Mg}$ and $\mathrm{Ag}$, as well as the investigation of the aforementioned relevant pathways in future studies. The aim of our study was to specifically harm the tumor cells with minimal damage to the healthy cells. This might not only be achieved by Ag but as a result of synergistic effects of $\mathrm{Ag}$ and $\mathrm{Mg}$ and hydrogen gas $\left(\mathrm{H}_{2}\right)$ evolution. $\mathrm{H}_{2}$ has been already studied to induce apoptosis in lung cancer cells [75]. Furthermore, Nan et al. reported $\mathrm{H}_{2}$ ability to scavenge free radicals in tumor cells. Interestingly, they generated $\mathrm{H}_{2}$ from degrading $\mathrm{Mg}$, suggesting $\mathrm{Mg}$ as a material with anti-bone cancer properties [76].

Aside from this, significantly increased relative tumor cell numbers in the dense model compared to the sparse model can be explained by contact inhibition. For healthy cells, cell proliferation progresses until close cell-cell contacts suppress further cell proliferation. Cells undergoing malignant transformation lose this suppression and are no longer limited to monolayers but grow vigorously in multilayers [77-79]. Therefore, a dense cell layer, like in the dense model, inhibits the proliferation of healthy cells, without affecting malignant cells. Consequently, the relative tumor cell number increases.

Another aspect that could be discussed here is the mechanical properties of the used biomaterials. Indeed, cell behavior is greatly influenced by the surface stiffness, as well as the topography of a 
material [80]. Here, the material topographies did not change significantly over time. However, compared to titanium, the magnesium materials have mechanical properties closer to the ones of bone. For example, the tensile strength of Ti-6Al-4V and cortical bone vary between 895 and $930 \mathrm{MPa}$ and 35 and $283 \mathrm{Mpa}$ [81], respectively, while the one of $\mathrm{Mg}$ and $\mathrm{Mg}-6 \mathrm{Ag}$ is about $108.3 \pm 3.1 \mathrm{Mpa}$ and $215.9 \pm 11.3 \mathrm{Mpa}$, respectively [82]. The Young's moduli, a common measure of material stiffness, of Ti-6Al-4V, Mg materials, and bones are about 110-114 Gpa, $45 \pm 1 \mathrm{Gpa}$, and 5-23 Gpa, respectively. Cancerous tissues have generally different mechanical characteristics (increased rigidity or stiffness) compared to healthy tissue, and these variations have been shown to influence the migration, proliferation, and metastasis of cells [83-85]. As such, the mechanical properties of the magnesium materials may also have a negative influence on the progression of the osteosarcoma cells. Further investigations on the mechanical properties of the Mg-degradation layer overtime are currently performed.

Our results indicated the suitability of Mg-based materials as antitumor systems. Regarding the here applied coculture consisting of the tumor and healthy cells, degrading materials seemed to increase relative cell numbers of healthy cells compared to non-degrading materials. Additionally, both cocultures-the sparse and dense system-were suitable mechanistic models to investigate different conditions after implantation of the materials. The sparse model might be applied to simulate the implant environment after a partial bone tumor resection, while the dense model might serve as a system to test unresectable areas.

\section{Materials and Methods}

\subsection{Cell Culture}

Human osteosarcoma cell line Saos-2, constitutively expressing the enhanced green fluorescent protein (eGFP), was provided by the research group of Prof. Tognon (Saos-eGFP). The engineered cell line Saos-eGFP was genetically modified to express constitutively the enhanced green fluorescent protein. Cell line characterization details can be found here [86]. Red fluorescent primary human dermal fibroblasts expressing FP602 (RF fibroblasts) were obtained from Innoprot (Innoprot, Derio, Spain). Both cell types were cultured in Dulbecco's Modified Eagle Medium GlutaMAX-I (DMEM GlutaMAX-I; Life Technologies, Darmstadt, Germany) supplemented with $10 \%$ fetal bovine serum (FBS, Merck KGaA, Darmstadt, Germany) under cell culture conditions $\left(37^{\circ} \mathrm{C}, 5 \% \mathrm{CO}_{2}, 95 \%\right.$ relative humidity (rH)).

\subsection{Material Surface Treatment and Cleaning Procedure}

$\mathrm{Mg}(99.95 \%)$ and $\mathrm{Mg}-6 \mathrm{Ag}$ (Mg with 6 weight $\% \mathrm{Ag}$ ) were produced by permanent mold gravity casting (Helmholtz-Zentrum Geesthacht, Geesthacht, Germany) and extruded into rods $(10 \mathrm{~mm}$ diameter). The rods were processed $(9 \mathrm{~mm}$ diameter) and cut into disks (1.5 $\mathrm{mm}$ thickness; Henschel KG, Munich, Germany). Disks were ground (Saphir 360 from ATM GmbH, Mammelzen, Germany) on both sides using SiC 2500 grid paper (Starcke GmbH \& Co.KG, Melle, Germany) at 80 rpm. Afterward, the samples were cleaned ultrasonically (Branson 1210, Branson Ultrasonics, Danbury, USA) for $20 \mathrm{~min}$ each in n-hexan, acetone, and 100\% ethanol and sterilized in 70\% ethanol (all chemicals from Merck KGaA, Darmstadt, Germany). Samples were then immersed in 2 mL DMEM supplemented with $10 \%$ FBS, starting the degradation experiments without cells, or preincubated in the medium for $24 \mathrm{~h}$ prior to experiments, including cells. Ti-6Al-4V (control) samples were cut from a round bar (F.W. Hempel Legierungsmetall GmbH and Co. KG, Oberhausen, Germany; $10 \mathrm{~mm}$ diameter $\times 2 \mathrm{~mm}$ height). Samples were polished, ultrasonically cleaned in $2 \%$ Hellmanex II solution (Hellma Materials $\mathrm{GmbH}$, Jena, Germany), chloroform, and 100\% ethanol (both chemicals from Merck KGaA, Darmstadt, Germany) (20 min each), and sterilized, as described above. 


\subsection{Osteosarcoma-Fibroblast Coculture on Mg-Based Materials}

For coculture experiments, Saos-eGFP and RF fibroblasts were dissociated using $0.05 \%$ trypsin-EDTA (Life Technologies GmbH, Darmstadt, Germany). The cells were then counted using a CASY Cell Counter (Roche Diagnostics GmbH, Mannheim, Germany), and a cell suspension with a 1:1 ratio of Saos-eGFP and RF fibroblasts was prepared. Monocultures of 10,000 Saos-eGFP or RF fibroblasts on material served as additional controls. A volume of $40 \mu \mathrm{L}$ containing 10,000 or 50,000 cells in total was directly seeded on the material surface and allowed to adhere for 20 min under cell culture conditions. Afterward, media ( $2 \mathrm{~mL}$ of DMEM supplemented with 10\% FBS) were added to each well and changed every 2-3 days. Corresponding materials without cells (Mg, Mg-6Ag), non-degrading material (Ti-6Al-4V), cells on tissue culture plate (cell control), and medium without material and cells (medium control) were selected as controls.

Microscopic images of the whole material surfaces were taken one, three, and seven days after cell seeding using an upright fluorescence microscope (Eclipse Ni-E; Nikon GmbH, Dusseldorf, Germany) and analyzed using ImageJ (Rasband, W.S., ImageJ, U.S. National Institutes of Health, Bethesda, Maryland, USA, https://imagej.nih.gov/ij/, 1997-2018). Cell numbers of both cell types were counted by analyzing particles and calculated as the ratio of the total cell number. The proportion of material covered with cells was determined as the quotient of the area covered by cells and the total surface area of the material.

\subsection{Determination of Mean Degradation Rate, $p H$, and Osmolality}

The mean degradation rates of the Mg-based materials (with or without cells) were measured by mass loss. Therefore, between the cleaning step with $100 \%$ ethanol and sterilization in $70 \%$ ethanol, the samples were dried and weighted using a micro-scale (Scaletec, Scaltec Instruments GmbH, Göttingen, Germany) to measure the initial weight. The samples were then immersed in a 24-well plate (Greiner Bio-One International GmbH, Kremsmünster, Austria) with 2 mL DMEM supplemented with 10\% FBS under cell culture conditions for seven days. Afterward, samples were rinsed in ultrapure $\mathrm{H}_{2} \mathrm{O}$ and ethanol and dried. To remove the residual degradation layer, the samples were immersed in chromic acid (180 g/L in distilled water, VWR International, Darmstadt, Germany) for 10 min, upended, and immersed for another $10 \mathrm{~min}$. Samples were again rinsed in ultrapure $\mathrm{H}_{2} \mathrm{O}$ and ethanol to remove residual chromic acid and dried. Afterward, the mass was measured again using a micro-scale and the mean degradation rate (MDR), as the average of the degradation rates (DR, $n=6)$ was calculated according to the following equation [87]:

$$
D R=\frac{K \times W}{A \times T \times D}
$$

$K$ is a constant $\left(K=8.76 \times 10^{4}\right.$ for degradation rate in $\left.\mathrm{mm} / \mathrm{a}\right), W$ is the mass loss in $\mathrm{g}, A$ is the area in $\mathrm{cm}^{2}, T$ is the immersion time in $\mathrm{h}$, and $D$ is the density in $\mathrm{g} / \mathrm{cm}^{3}$.

Supernatants were taken on days 1,3, and 7 after cell seeding for analysis of $\mathrm{pH}$ and osmolality, and the fresh medium was added on these time points. The $\mathrm{pH}$ was measured using a $\mathrm{pH}$ meter with an ion-sensitive field-effect transistor (ISFET) pH sensor (Sentron SI600, Sentron Europe BV, Roden, The Netherlands). The osmolality was measured using the freezing point osmometer 'Osmomat Auto' (Gonotec GmbH, Berlin, Germany).

\subsection{Interferometry}

Surface topography of the initial and degraded material was conducted via white light interferometry using a non-contact interferometer (contour GT-K, Bruker Corporation, Billerica, MA, USA). Samples were either in the initial state or after degradation for seven days (sparse and dense model) after removing the degradation layer using chromic acid. The raw data was analyzed using the software "Vision64" (v. 4.51, Bruker Corporation, Billerica, MA, USA). First, resulting images 
of the material surface were corrected regarding their form (cylindrical) and tilted with an F-operator as well as cropped with a circle mask. The 3D Analysis Tool "S Parameters-Height" determined the average roughness (Sa), the maximum peak height (Sp), and the maximum valley depth (Sv) to compare respective samples with the two different seeding densities.

\subsection{Quantification of $\mathrm{Mg}$ and $\mathrm{Ag}$ Contents in Degradation Supernatants}

Due to possible emission spectrum interferences between $\mathrm{Ag}$ and $\mathrm{Mg}$, element releases (Ag and $\mathrm{Mg}$ ) during degradation were quantified either via AAS (for Mg samples) or ICP-MS (for Mg-6Ag samples). Prior to AAS analysis, the supernatants were acidified with $1 \%(w / v)$ nitric acid $\left(\mathrm{HNO}_{3}\right.$, Merck KGaA, Darmstadt, Germany) and kept at $4{ }^{\circ} \mathrm{C}$ to avoid precipitation. Then, samples were diluted 1:250 in $1 \% \mathrm{HNO}_{3}$ in ultrapure $\mathrm{H}_{2} \mathrm{O}$, and total $\mathrm{Mg}$ concentration was detected using a flame AAS (Agilent 240 AA, Agilent Technologies, Waldbronn, Germany) at a wavelength of $285.2 \mathrm{~nm}$ (emission spectrum of $\mathrm{Mg}$ ). A calibration curve ranging from 0.05 to $1 \mathrm{mg} / \mathrm{L} \mathrm{Mg}$ was applied for quantification. ICP-MS was applied to quantify the concentration of $\mathrm{Mg}$ and $\mathrm{Ag}$ in the supernatant after $\mathrm{Mg}-6 \mathrm{Ag}$ degradation. To avoid contaminations, digiTUBEs (S-prep GmbH, Überlingen, Germany) were flushed twice with ultrapure water and $1 \%(w / v) \mathrm{HNO}_{3}$ in ultrapure water. Supernatants acidified in $1 \%(w / v) \mathrm{HNO}_{3}$ were diluted $1: 1000-2000$ in $1 \%(w / v) \mathrm{HNO}_{3}$ in ultrapure water to a final volume of $30 \mathrm{~mL}$ in digiTUBES. The concentrations of $\mathrm{Mg}$ and $\mathrm{Ag}$ were determined by an inductively-coupled plasma-mass spectrometer (Agilent 7900 ICP-MS, Agilent Technologies, Waldbronn, Germany) with an ESI PFA microflow nebulizer (Elemental Scientific, Omaha, NE, USA).

\subsection{Statistics}

The data were obtained from three independent experiments with three samples and are shown as the arithmetic mean \pm standard deviation (SD), if not stated otherwise. Statistical analysis (Prism 6, GraphPad Software, La Jolla, CA, USA) was conducted in two ways, either comparing the mean of respective samples of the dense and sparse coculture model using an unpaired non-parametric t-test (Mann-Whitney test) or comparing both models with a no-cell control using non-parametric one-way analysis of variances (ANOVA) (Kruskal-Wallis test) with Dunn's multiple comparison test.

\section{Conclusions}

In this study, we used a coculture model of the tumor microenvironment (osteosarcoma-fibroblast) that allowed the direct observation of cell population evolution, especially on opaque material, thanks to cell-specific fluorescence.

Depending on the degradation rate, $\mathrm{Mg}$ and $\mathrm{Mg}-6 \mathrm{Ag}$ decreased relative tumor cell numbers in contrast to non-degrading Ti-based material. This effect was assumed to be degradation-dependent since the proliferation rates of the used healthy and tumor cells were found to be comparable. From our preliminary data, we concluded that the used Mg-based materials rather exerted cytostatic than cytotoxic effects on the tumor cells, therefore lowering the relative number of tumor cells. Increasing the degradation rate of the material accompanied by increasing surface effects ( $\mathrm{pH}$, osmolality, $\mathrm{H}_{2}$ release) might result in rather cytotoxic effects. Comparing a sparse (10,000 cells in total) and dense (50,000 cells in total) variant of the coculture model, the proportion of fibroblasts tended to be higher in the sparse coculture model. This indicated better effects of Mg-based material surrounded by only a few tumor cells, as it could be expected in vivo directly after tumor resection. Although the cell densities were significantly different, the degradation influence on the coculture did not seem to be different between both coculture models, indicating cell-density independence. Further studies should focus on the crosstalk of fibroblasts and tumor cells in this coculture dependent on $\mathrm{Mg}$ material degradation. It is also conceivable to test other cells of the TME or extend the present coculture with additional relevant cell types (macrophages, endothelial cells). Additionally, to mimic better the tumor microenvironment, a more complex in vitro system will be developed to also monitor the effect 
of $\mathrm{Mg}$ and its alloys on angiogenesis (with endothelial cells) and inflammatory environment (with macrophage-immune cells).

We concluded that the sparse coculture model, showing more resolute effects with $\mathrm{Mg}$, is a suitable mechanistic system to study possible antitumor effects of Mg-based materials, which will be part of our future work.

Author Contributions: Conceptualization, P.G. and B.J.C.L.-F.; Formal analysis, P.G.; Funding acquisition, R.W.-R. and B.J.C.L.-F.; Investigation, P.G.; Methodology, P.G. and B.J.C.L.-F.; Project administration, R.W.-R. and B.J.C.L.-F.; Resources, F.M. and E.M.; Supervision, R.W.-R. and B.J.C. L.-F.; Validation, P.G.; Visualization, P.G.; Writing-original draft, P.G.; Writing-review and editing, P.G., R.W.-R., and B.J.C.L.-F. All authors have read and agreed to the published version of the manuscript.

Funding: This work was funded by the Helmholtz - Russian Science Foundation Joint Research Groups HRSF-0025.

Acknowledgments: The authors thank Björn Wiese for manufacturing the extruded $\mathrm{Mg}$ and $\mathrm{Mg}-6 \mathrm{Ag}$ and Heike Helmholz for conducting the AAS measurement. The department "Marine Bioanalytical Chemistry", led by Daniel Pröffrock in Helmholtz-Zentrum Geesthacht, is acknowledged for conducting the ICP-MS measurements. F.M. acknowledges the grant MIUR PRIN 2017.

Conflicts of Interest: The authors declare no conflict of interest. The funders had no role in the design of the study; in the collection, analyses, or interpretation of data; in the writing of the manuscript, or in the decision to publish the results.

\section{Abbreviations}
AAS Atomic absorption spectroscopy
ICP Inductively-coupled plasma
MDR Mean degradation rate
MS Mass spectrometry
OS Osteosarcoma
TME Tumor microenvironment

\section{Appendix A}

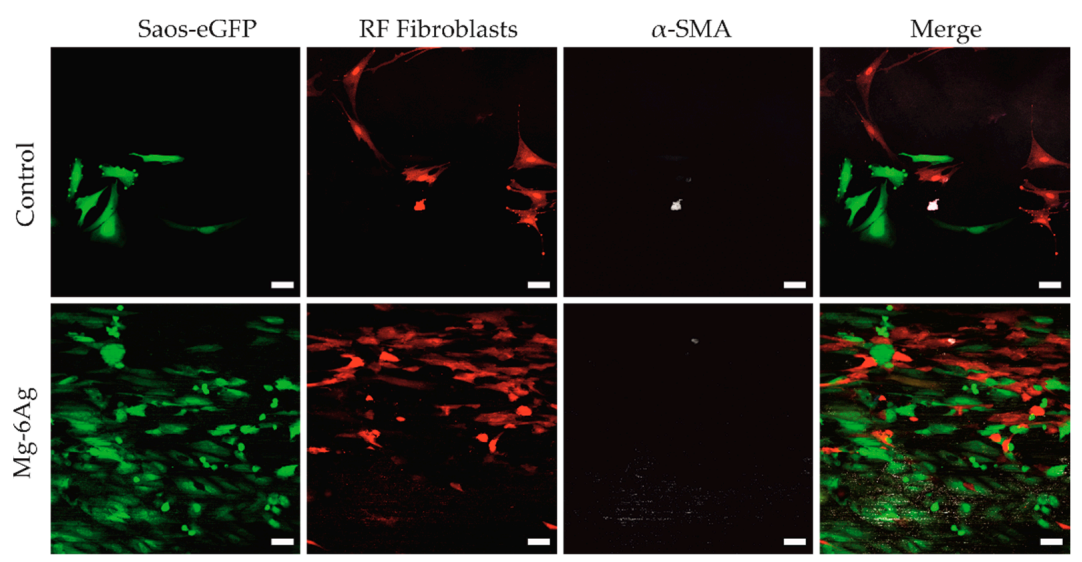

Figure A1. Exclusion of cancer-associated fibroblast (CAF) phenotype for RF fibroblasts. Saos-eGFP (green) and RF fibroblasts (red) were stained for $\alpha$-smooth muscle actin ( $\alpha$-SMA) (white). RF fibroblasts were negative for $\alpha$-SMA, indicating that they did not transform to CAFs in the presence of Saos-eGFP. Scale bar is $10 \mu \mathrm{m}$.

\section{References}

1. Picci, P. Osteosarcoma (osteogenic sarcoma). Orphanet J. Rare Dis. 2007, 2, 6. [CrossRef] [PubMed]

2. Ottaviani, G.; Jaffe, N. The epidemiology of osteosarcoma. Cancer Treat. Res. 2009, 152, 3-13. [PubMed]

3. Smith, M.A.; Seibel, N.L.; Altekruse, S.F.; Ries, L.A.; Melbert, D.L.; O'Leary, M.; Smith, F.O.; Reaman, G.H. Outcomes for children and adolescents with cancer: Challenges for the twenty-first century. J. Clin. Oncol. 2010, 28, 2625-2634. [CrossRef] [PubMed] 
4. Smith, M.A.; Altekruse, S.F.; Adamson, P.C.; Reaman, G.H.; Seibel, N.L. Declining childhood and adolescent cancer mortality. Cancer 2014, 120, 2497-2506. [CrossRef] [PubMed]

5. Biazzo, A.; De Paolis, M. Multidisciplinary approach to osteosarcoma. Acta Orthop. Belg. 2016, 82, 690-698. [PubMed]

6. Kundu, Z.S. Classification, imaging, biopsy and staging of osteosarcoma. Indian J. Orthop. 2014, 48, 238-246. [CrossRef]

7. Bielack, S.; Kempf-Bielack, B.; Von Kalle, T.; Schwarz, R.; Wirth, T.; Kager, L.; Whelan, J. Controversies in childhood osteosarcoma. Minerva Pediatr. 2013, 65, 125-148.

8. Misaghi, A.; Goldin, A.; Awad, M.; Kulidjian, A.A. Osteosarcoma: A comprehensive review. SICOT-J 2018, 4, 12. [CrossRef]

9. Harrison, D.J.; Geller, D.S.; Gill, J.D.; Lewis, V.O.; Gorlick, R. Current and future therapeutic approaches for osteosarcoma. Expert Rev. Anticancer Ther. 2018, 18, 39-50. [CrossRef]

10. Meyers, P.A. Systemic therapy for osteosarcoma and ewing sarcoma. In American Society of Clinical Oncology Educational Book; American Society of Clinical Oncology: Alexandria, VA, USA, 2015; pp. e644-e647. [CrossRef]

11. Anninga, J.K.; Gelderblom, H.; Fiocco, M.; Kroep, J.R.; Taminiau, A.H.; Hogendoorn, P.C.; Egeler, R.M. Chemotherapeutic adjuvant treatment for osteosarcoma: Where do we stand? Eur. J. Cancer 2011, 47, 2431-2445. [CrossRef]

12. Lee, B.K.; Yun, Y.H.; Park, K.; Sturek, M. 1-Introduction to biomaterials for cancer therapeutics. In Biomaterials for Cancer Therapeutics; Park, K., Ed.; Woodhead Publishing: Sawston, UK, 2013; pp. 3-19.

13. Witte, F. The history of biodegradable magnesium implants: A review. Acta Biomater. 2010, 6, 1680-1692. [CrossRef] [PubMed]

14. Zhang, Y.; Ren, L.; Li, M.; Lin, X.; Zhao, H.; Yang, K. Preliminary study on cytotoxic effect of biodegradation of magnesium on cancer cells. J. Mater. Sci. Technol. 2012, 28, 769-772. [CrossRef]

15. Wang, Q.; Jin, S.; Lin, X.; Zhang, Y.; Ren, L.; Yang, K. Cytotoxic effects of biodegradation of pure mg and mao-mg on tumor cells of mg63 and kb. J. Mater. Sci. Technol. 2014, 30, 487-492. [CrossRef]

16. Li, M.; Ren, L.; Li, L.; He, P.; Lan, G.; Zhang, Y.; Yang, K. Cytotoxic effect on osteosarcoma mg-63 cells by degradation of magnesium. J. Mater. Sci. Technol. 2014, 30, 888-893. [CrossRef]

17. Liu, Z.; Schade, R.; Luthringer, B.; Hort, N.; Rothe, H.; Muller, S.; Liefeith, K.; Willumeit-Romer, R.; Feyerabend, F. Influence of the microstructure and silver content on degradation, cytocompatibility, and antibacterial properties of magnesium-silver alloys In Vitro. Oxid. Med. Cell Longev. 2017, 2017, 8091265. [CrossRef]

18. Cameron, S.J.; Hosseinian, F.; Willmore, W.G. A current overview of the biological and cellular effects of nanosilver. Int. J. Mol. Sci. 2018, 19, 2030. [CrossRef]

19. Franco-Molina, M.A.; Mendoza-Gamboa, E.; Sierra-Rivera, C.A.; Gomez-Flores, R.A.; Zapata-Benavides, P.; Castillo-Tello, P.; Alcocer-Gonzalez, J.M.; Miranda-Hernandez, D.F.; Tamez-Guerra, R.S.; Rodriguez-Padilla, C. Antitumor activity of colloidal silver on mcf-7 human breast cancer cells. J. Exp. Clin. Cancer Res. 2010, 29, 148. [CrossRef]

20. Fischer, J.; Pröfrock, D.; Hort, N.; Willumeit, R.; Feyerabend, F. Improved cytotoxicity testing of magnesium materials. Mater. Sci. Eng. B 2011, 176, 830-834. [CrossRef]

21. Duner, S.; Lopatko Lindman, J.; Ansari, D.; Gundewar, C.; Andersson, R. Pancreatic cancer: The role of pancreatic stellate cells in tumor progression. Pancreatology 2010, 10, 673-681. [CrossRef]

22. Liotta, L.A.; Kohn, E.C. The microenvironment of the tumour-host interface. Nature 2001, 411, 375-379. [CrossRef]

23. Kalluri, R. The biology and function of fibroblasts in cancer. Nat. Rev. Cancer 2016, 16, 582-598. [CrossRef] [PubMed]

24. Kalluri, R.; Zeisberg, M. Fibroblasts in cancer. Nat. Rev. Cancer 2006, 6, 392-401. [CrossRef] [PubMed]

25. Ohlund, D.; Elyada, E.; Tuveson, D. Fibroblast heterogeneity in the cancer wound. J. Exp. Med. 2014, 211, 1503-1523. [CrossRef] [PubMed]

26. Stelling, M.P.; Motta, J.M.; Mashid, M.; Johnson, W.E.; Pavao, M.S.; Farrell, N.P. Metal ions and the extracellular matrix in tumor migration. FEBS J. 2019, 286, 2950-2964. [CrossRef]

27. Leidi, M.; Wolf, F.; Maier, J.A.M. Magnesium and cancer: More questions than answers. In Magnesium in the Central Nervous System; Vink, R., Nechifor, M., Eds.; University of Adelaide Press: Adelaide, Australia, 2011. 
28. Yue, H.; Uzui, H.; Lee, J.D.; Shimizu, H.; Ueda, T. Effects of magnesium on matrix metalloproteinase-2 production in cultured rat cardiac fibroblasts. Basic Res. Cardiol. 2004, 99, 257-263. [CrossRef]

29. Nasulewicz, A.; Wietrzyk, J.; Wolf, F.I.; Dzimira, S.; Madej, J.; Maier, J.A.; Rayssiguier, Y.; Mazur, A.; Opolski, A. Magnesium deficiency inhibits primary tumor growth but favors metastasis in mice. Biochim. Biophys. Acta 2004, 1739, 26-32. [CrossRef]

30. Salvatore, V.; Focaroli, S.; Teti, G.; Mazzotti, A.; Falconi, M. Changes in the gene expression of co-cultured human fibroblast cells and osteosarcoma cells: The role of microenvironment. Oncotarget 2015, 6, 28988-28998. [CrossRef]

31. Martinez-Outschoorn, U.E.; Balliet, R.M.; Rivadeneira, D.B.; Chiavarina, B.; Pavlides, S.; Wang, C.; Whitaker-Menezes, D.; Daumer, K.M.; Lin, Z.; Witkiewicz, A.K.; et al. Oxidative stress in cancer associated fibroblasts drives tumor-stroma co-evolution: A new paradigm for understanding tumor metabolism, the field effect and genomic instability in cancer cells. Cell Cycle 2010, 9, 3256-3276. [CrossRef]

32. Angelucci, C.; Maulucci, G.; Lama, G.; Proietti, G.; Colabianchi, A.; Papi, M.; Maiorana, A.; De Spirito, M.; Micera, A.; Balzamino, O.B.; et al. Epithelial-stromal interactions in human breast cancer: Effects on adhesion, plasma membrane fluidity and migration speed and directness. PLoS ONE 2012, 7, e50804. [CrossRef]

33. Fujiwara, M.; Kanayama, K.; Hirokawa, Y.S.; Shiraishi, T. Asf-4-1 fibroblast-rich culture increases chemoresistance and mtor expression of pancreatic cancer bxpc-3 cells at the invasive front In Vitro, and promotes tumor growth and invasion in vivo. Oncol. Lett. 2016, 11, 2773-2779. [CrossRef]

34. Kuen, J.; Darowski, D.; Kluge, T.; Majety, M. Pancreatic cancer cell/fibroblast co-culture induces m2 like macrophages that influence therapeutic response in a 3d model. PLoS ONE 2017, 12, e0182039. [CrossRef] [PubMed]

35. Mesker, W.E.; Junggeburt, J.M.C.; Szuhai, K.; de Heer, P.; Morreau, H.; Tanke, H.J.; Tollenaar, R.A.E.M. The carcinoma-stromal ratio of colon carcinoma is an independent factor for survival compared to lymph node status and tumor stage. Cell. Oncol. Off. J. Int. Soc. Cell. Oncol. 2007, 29, 387-398.

36. Seuss, F.; Seuss, S.; Turhan, M.C.; Fabry, B.; Virtanen, S. Corrosion of mg alloy az91d in the presence of living cells. J. Biomed. Mater. Res. Part B Appl. Biomater. 2011, 99B, 276-281. [CrossRef] [PubMed]

37. Wagener, V.; Schilling, A.; Mainka, A.; Hennig, D.; Gerum, R.; Kelch, M.L.; Keim, S.; Fabry, B.; Virtanen, S. Cell adhesion on surface-functionalized magnesium. ACS Appl. Mater. Interfaces 2016, 8, 11998-12006. [CrossRef]

38. Kannan, M.B.; Yamamoto, A.; Khakbaz, H. Influence of living cells (1929) on the biodegradation of magnesium-calcium alloy. Colloids Surf. B Biointerfaces 2015, 126, 603-606. [CrossRef] [PubMed]

39. Brooks, E.K.; Tobias, M.E.; Yang, S.; Bone, L.B.; Ehrensberger, M.T. Influence of mc3t3-e1 preosteoblast culture on the corrosion of a t6-treated az91 alloy. J. Biomed. Mater. Res. B Appl. Biomater. 2016, 104, 253-262. [CrossRef]

40. Zhang, J.; Hiromoto, S.; Yamazaki, T.; Niu, J.; Huang, H.; Jia, G.; Li, H.; Ding, W.; Yuan, G. Effect of macrophages on in vitro corrosion behavior of magnesium alloy. J. Biomed. Mater. Res. A 2016, 104, 2476-2487. [CrossRef]

41. Cecchinato, F.; Agha, N.A.; Martinez-Sanchez, A.H.; Luthringer, B.J.; Feyerabend, F.; Jimbo, R.; Willumeit-Romer, R.; Wennerberg, A. Influence of magnesium alloy degradation on undifferentiated human cells. PLoS ONE 2015, 10, e0142117. [CrossRef]

42. Burmester, A.; Luthringer, B.; Willumeit, R.; Feyerabend, F. Comparison of the reaction of bone-derived cells to enhanced mgcl2-salt concentrations. Biomatter 2014, 4, e967616. [CrossRef]

43. Burmester, A.; Willumeit-Romer, R.; Feyerabend, F. Behavior of bone cells in contact with magnesium implant material. J. Biomed. Mater. Res. B Appl. Biomater. 2017, 105, 165-179. [CrossRef]

44. Czekanska, E.M.; Stoddart, M.J.; Richards, R.G.; Hayes, J.S. In search of an osteoblast cell model for in vitro research. Eur. Cell. Mater. 2012, 24, 1-17. [CrossRef] [PubMed]

45. Czekanska, E.M.; Stoddart, M.J.; Ralphs, J.R.; Richards, R.G.; Hayes, J.S. A phenotypic comparison of osteoblast cell lines versus human primary osteoblasts for biomaterials testing. J. Biomed. Mater. Res. Part A 2014, 102, 2636-2643. [CrossRef] [PubMed]

46. Xu, L.; Willumeit-Römer, R.; Luthringer-Feyerabend, B.J.C. Effect of magnesium-degradation products and hypoxia on the angiogenesis of human umbilical vein endothelial cells. Acta Biomater. 2019, 98, 269-283. [CrossRef] 
47. Costantino, M.D.; Schuster, A.; Helmholz, H.; Meyer-Rachner, A.; Willumeit-Romer, R.; Luthringer-Feyerabend, B.J.C. Inflammatory response to magnesium-based biodegradable implant materials. Acta Biomater. 2020, 101, 598-608. [CrossRef] [PubMed]

48. Ahmad Agha, N.; Willumeit-Römer, R.; Laipple, D.; Luthringer, B.; Feyerabend, F. The degradation interface of magnesium based alloys in direct contact with human primary osteoblast cells. PLoS ONE 2016, 11, e0157874. [CrossRef]

49. Gonzalez, J.; Hou, R.Q.; Nidadavolu, E.P.S.; Willumeit-Romer, R.; Feyerabend, F. Magnesium degradation under physiological conditions - best practice. Bioact. Mater. 2018, 3, 174-185. [CrossRef]

50. Jung, O.; Smeets, R.; Hartjen, P.; Schnettler, R.; Feyerabend, F.; Klein, M.; Wegner, N.; Walther, F.; Stangier, D.; Henningsen, A.; et al. Improved in vitro test procedure for full assessment of the cytocompatibility of degradable magnesium based on iso 10993-5/-12. Int. J. Mol. Sci. 2019, 20, 255. [CrossRef]

51. Li, L.; Zhang, M.; Li, Y.; Zhao, J.; Qin, L.; Lai, Y. Corrosion and biocompatibility improvement of magnesium-based alloys as bone implant materials: A review. Regen. Biomater. 2017, 4, 129-137. [CrossRef]

52. Wong, H.M.; Yeung, K.W.K.; Lam, K.O.; Tam, V.; Chu, P.K.; Luk, K.D.K.; Cheung, K.M.C. A biodegradable polymer-based coating to control the performance of magnesium alloy orthopaedic implants. Biomaterials 2010, 31, 2084-2096. [CrossRef]

53. Jo, J.-H.; Kang, B.-G.; Shin, K.-S.; Kim, H.-E.; Hahn, B.-D.; Park, D.-S.; Koh, Y.-H. Hydroxyapatite coating on magnesium with mgf2 interlayer for enhanced corrosion resistance and biocompatibility. J. Mater. Sci. Mater. Med. 2011, 22, 2437-2447. [CrossRef]

54. Keim, S.; Brunner, J.G.; Fabry, B.; Virtanen, S. Control of magnesium corrosion and biocompatibility with biomimetic coatings. J. Biomed. Mater. Res. B Appl. Biomater. 2011, 96, 84-90. [CrossRef] [PubMed]

55. Lu, P.; Cao, L.; Liu, Y.; Xu, X.; Wu, X. Evaluation of magnesium ions release, biocorrosion, and hemocompatibility of mao/plla-modified magnesium alloy we42. J. Biomed. Mater. Res. B Appl. Biomater. 2011, 96, 101-109. [CrossRef] [PubMed]

56. Huan, Z.G.; Leeflang, M.A.; Zhou, J.; Fratila-Apachitei, L.E.; Duszczyk, J. In Vitro degradation behavior and cytocompatibility of mg-zn-zr alloys. J. Mater. Sci. Mater. Med. 2010, 21, 2623-2635. [CrossRef] [PubMed]

57. Gu, X.N.; Li, N.; Zheng, Y.F.; Ruan, L. In Vitro degradation performance and biological response of a mg-zn-zr alloy. Mater. Sci. Eng. B 2011, 176, 1778-1784. [CrossRef]

58. Wolf, F.I.; Cittadini, A.R.; Maier, J.A. Magnesium and tumors: Ally or foe? Cancer Treat. Rev. 2009, 35, 378-382. [CrossRef] [PubMed]

59. Anghileri, L.J. Magnesium, calcium and cancer. Magnes. Res. 2009, 22, 247-255. [CrossRef]

60. Koppenol, W.H.; Bounds, P.L.; Dang, C.V. Otto warburg's contributions to current concepts of cancer metabolism. Nat. Rev. Cancer 2011, 11, 325-337. [CrossRef]

61. Gunther, T. Comment on the number of mg2+-activated enzymes. Magnes. Res. 2008, 21, 185-187.

62. Sun, Y.; Selvaraj, S.; Varma, A.; Derry, S.; Sahmoun, A.E.; Singh, B.B. Increase in serum ca2+/mg2+ ratio promotes proliferation of prostate cancer cells by activating trpm7 channels. J. Biol. Chem. 2013, 288, 255-263. [CrossRef]

63. Pereira, M.; Millot, J.-M.; Sebille, S.; Manfait, M. Inhibitory effects of extracellular mg2+ on intracellular ca2+ dynamic changes and thapsigargin-induced apoptosis in human cancer mcf7 cells. Mol. Cell. Biochem. 2002, 229, 163-171. [CrossRef]

64. Pinto, M.C.; Kihara, A.H.; Goulart, V.A.; Tonelli, F.M.; Gomes, K.N.; Ulrich, H.; Resende, R.R. Calcium signaling and cell proliferation. Cell. Signal. 2015, 27, 2139-2149. [CrossRef] [PubMed]

65. Smyth, J.T.; Hwang, S.Y.; Tomita, T.; DeHaven, W.I.; Mercer, J.C.; Putney, J.W. Activation and regulation of store-operated calcium entry. J. Cell Mol. Med. 2010, 14, 2337-2349. [CrossRef] [PubMed]

66. Yoshimura, M.; Oshima, T.; Matsuura, H.; Ishida, T.; Kambe, M.; Kajiyama, G. Extracellular mg2+ inhibits capacitative ca2+ entry in vascular smooth muscle cells. Circulation 1997, 95, 2567-2572. [CrossRef] [PubMed]

67. Zhu, Z.; Tepel, M.; Spieker, C.; Zidek, W. Effect of extracellular mg2+ concentration on agonist-induced cytosolic free ca2+ transients. Biochim. Biophys. Acta 1995, 1265, 89-92. [CrossRef]

68. Banti, C.N.; Giannoulis, A.D.; Kourkoumelis, N.; Owczarzak, A.M.; Poyraz, M.; Kubicki, M.; Charalabopoulos, K.; Hadjikakou, S.K. Mixed ligand-silver(i) complexes with anti-inflammatory agents which can bind to lipoxygenase and calf-thymus DNA, modulating their function and inducing apoptosis. Metallomics 2012, 4, 545-560. [CrossRef] 
69. Banti, C.N.; Hadjikakou, S.K. Anti-proliferative and anti-tumor activity of silver(i) compounds. Metallomics 2013, 5, 569-596. [CrossRef]

70. Durai, P.; Chinnasamy, A.; Gajendran, B.; Ramar, M.; Pappu, S.; Kasivelu, G.; Thirunavukkarasu, A. Synthesis and characterization of silver nanoparticles using crystal compound of sodium para-hydroxybenzoate tetrahydrate isolated from vitex negundo. L leaves and its apoptotic effect on human colon cancer cell lines. Eur. J. Med. Chem. 2014, 84, 90-99. [CrossRef]

71. Kovács, D.; Igaz, N.; Keskeny, C.; Bélteky, P.; Tóth, T.; Gáspár, R.; Madarász, D.; Rázga, Z.; Kónya, Z.; Boros, I.M.; et al. Silver nanoparticles defeat p53-positive and p53-negative osteosarcoma cells by triggering mitochondrial stress and apoptosis. Sci. Rep. 2016, 6, 27902. [CrossRef]

72. Kaplan, A.; Akalin Ciftci, G.; Kutlu, H.M. Cytotoxic, anti-proliferative and apoptotic effects of silver nitrate against h-ras transformed 5rp7. Cytotechnology 2016, 68, 1727-1735. [CrossRef]

73. Gao, S.; Chen, D.; Li, Q.; Ye, J.; Jiang, H.; Amatore, C.; Wang, X. Near-infrared fluorescence imaging of cancer cells and tumors through specific biosynthesis of silver nanoclusters. Sci. Rep. 2014, 4, 4384. [CrossRef]

74. Ostad, S.N.; Dehnad, S.; Nazari, Z.E.; Fini, S.T.; Mokhtari, N.; Shakibaie, M.; Shahverdi, A.R. Cytotoxic activities of silver nanoparticles and silver ions in parent and tamoxifen-resistant $47 \mathrm{~d}$ human breast cancer cells and their combination effects with tamoxifen against resistant cells. Avicenna J. Med. Biotechnol. 2010, 2, 187-196.

75. Wang, D.; Wang, L.; Zhang, Y.; Zhao, Y.; Chen, G. Hydrogen gas inhibits lung cancer progression through targeting smc3. Biomed. Pharmacother. 2018, 104, 788-797. [CrossRef] [PubMed]

76. Nan, M.; Yangmei, C.; Bangcheng, Y. Magnesium metal-A potential biomaterial with antibone cancer properties. J. Biomed. Mater. Res. Part A 2014, 102, 2644-2651. [CrossRef] [PubMed]

77. Hanahan, D.; Weinberg, R.A. Hallmarks of cancer: The next generation. Cell 2011, 144, 646-674. [CrossRef]

78. Abercrombie, M. Contact inhibition in tissue culture. In Vitro 1970, 6, 128-142. [CrossRef] [PubMed]

79. Zheng, S.; Zhang, S.-Z.; Chen, K.; Zhu, Y.-L.; Dong, Q. 19-Research on colorectal cancer in china. In Recent Advances in Cancer Research and Therapy; Liu, X.-Y., Pestka, S., Shi, Y.-F., Eds.; Elsevier: Oxford, UK, 2012; pp. 535-595.

80. Janmey, P.A.; Fletcher, D.A.; Reinhart-King, C.A. Stiffness sensing by cells. Physiol. Rev. 2020, 100, 695-724. [CrossRef] [PubMed]

81. Luthringer, B.J.; Feyerabend, F.; Willumeit-Romer, R. Magnesium-based implants: A mini-review. Magnes. Res. 2014, 27, 142-154. [CrossRef]

82. Tie, D.; Feyerabend, F.; Müller, W.D.; Schade, R.; Liefeith, K.; Kainer, K.U.; Willumeit, R. Antibacterial biodegradable mg-ag alloys. Eur. Cell. Mater. 2013, 25, 284-298. [CrossRef]

83. Evans, N.D.; Gentleman, E. The role of material structure and mechanical properties in cell-matrix interactions. J. Mater. Chem. B 2014, 2, 2345-2356. [CrossRef]

84. Ulrich, T.A.; de Juan Pardo, E.M.; Kumar, S. The mechanical rigidity of the extracellular matrix regulates the structure, motility, and proliferation of glioma cells. Cancer Res. 2009, 69, 4167-4174. [CrossRef]

85. Zaman, M.H.; Trapani, L.M.; Sieminski, A.L.; Mackellar, D.; Gong, H.; Kamm, R.D.; Wells, A.; Lauffenburger, D.A.; Matsudaira, P. Migration of tumor cells in 3d matrices is governed by matrix stiffness along with cell-matrix adhesion and proteolysis. Proc. Natl. Acad. Sci. USA 2006, 103, 10889-10894. [CrossRef] [PubMed]

86. Morelli, C.; Barbanti-Brodano, G.; Ciannilli, A.; Campioni, K.; Boriani, S.; Tognon, M. Cell morphology, markers, spreading, and proliferation on orthopaedic biomaterials. An innovative cellular model for the "In Vitro" study. J. Biomed. Mater. Res. A 2007, 83, 178-183. [CrossRef] [PubMed]

87. ASTM. ASTM G31-72(2004), Standard Practice for Laboratory Immersion Corrosion Testing of Metals; ASTM International: West Conshohocken, PA, USA, 2004.

(C) 2020 by the authors. Licensee MDPI, Basel, Switzerland. This article is an open access article distributed under the terms and conditions of the Creative Commons Attribution (CC BY) license (http://creativecommons.org/licenses/by/4.0/). 